\title{
К 100-летию доктора географических наук, профессора Забродской М.П. (1919-1994)
}

\author{
А. М. Луговской ${ }^{1}$, Л. А. Межова ${ }^{2} \bowtie$ \\ ${ }^{1}$ Московский государственный университет геодезии и картографии, Российская Федерачия \\ (105064, г. Москва, Гороховский пер., 4) \\ ${ }^{2}$ Воронежский государственный педагогический университет, Российская Федерачия \\ (394043, г. Воронеж, ул. Ленина, 86) \\ Поступила в редакиию 12.12.2019 \\ Принята к публикации 26.02.2020
}

\begin{abstract}
Аннотация: Цель - в связи со столетним юбилеем профессора Воронежского государственного педагогического университета Забродской Марии Павловны рассматривается вклад ученого, исследователя, методиста в развитии страноведения. В исследовательской деятельности Забродской М. П. значительное внимание уделено методике преподавания страноведения в вузе. В ее учебно-методических пособиях собран уникальный материал по физической географии Африки и разработаны практические задания по физической географии материков. В теоретических исследованиях по страноведению Мария Павловна изучала факторы пространственной дифференциации материков, проблемы физикогеографического районирования и природной зональности материков Южного Полушария с выявлением их ландшафтов аналогов. Автором был разработан комплексный подход в изучении страноведения и апробирован на примере Африки. Ее любовь к Африке нашла отражение в выпускниках, учителях.
\end{abstract}

Ключевые слова: страноведение, методист, ученый, исследователь, пространственно-временная дифференциация.

\section{To the 100th Anniversary of Doctor of Geographical Sciences, Professor M.P. Zabrodskaya (1919-1994)}

\section{A. M. Lugovskoy, L. A. Mezhova四}

Abstract: The works of Maria Pavlovna Zabrodskaya are very important for the development of country studies. She has been dealing with rather complicated issues in country studies: problems of physical and geographical zoning of Africa, at the same time she has considered in detail the issues of formation and development of methodological and methodical approach to their solution. The author identified the contribution of Russian travelers to the history of African studies and discovered new names of researchers. Of particular interest is the work devoted to the factors of spatial differentiation of continents and the study of geographical analogues of natural zones of Africa, Eurasia, Australia and South America. The author paid great attention to the development of lectures, practical classes and methodological recommendations for the study of physical geography of continents of Africa and South America. Her works have not lost their relevance at present and are of both methodological and scientific interest.

Key words: country studies, methodologist, scientist, researcher, space-time differentiation.

() Луговской А.М., Межова Л.А., 2020

$\triangle$ E-mail: lidiya09@rambler.ru

Контент доступен под лицензией Creative Commons Attribution 4.0 License.

The content is available under Creative Commons Attribution 4.0 License. 
В настоящее время, к сожалению, стали забывать имена ученых, исследователей, которые стояли у истоков развития географической науки в $\mathrm{XX}$ веке. XX век отмечен развитием новых направлений и подходов в географии. В области страноведения, наряду с такими именами, как А. М. Рябчиков, Т.В. Власова, Ю.Д. Дмитриевский, В.П. Максаковский, Г.В. Сдасюк, можно поставить имя Забродской Марии Павловны.

Профессор Мария Павловна Забродская - доктор географических наук автор книг и научных статей по проблемам физико-географического районирования материков, оценке природно-ресурсного потенциала территории Северной и СевероЗападной Африки, истории географических открытий и исследований, известный специалист по географии Африки.

М. П. Забродская родилась в 29 ноября 1919 года в Слободе Веслотская Базарского района Житомирской области. После окончания школы Мария Павловна поступает в Спасский педагогический техникум Московской области, который закончила в 1936 году по полному курсу школьного отделения и в этом же году поступила на географический факультет Московского областного педагогического института (в 2002 году вуз был переименован в Московский государственный областной университет). В то время на факультете успешно функционировало 5 кафедр - общей физической географии; страноведения; экономической географии; геологии; методики преподавания географии. В 1940 году Мария Павловна поступила в аспирантуру, а в 1947 году успешно защищает кандидатскую диссертацию по теме «Ландшафты Динарской Югославии». Ее оппонентами были доктор географических наук, профессор Боднарский М. С. и кандидат географических наук, доцент И.М. Иванов, который был первым деканом факультета - полярник, специалист по Арктике, зимовавший на Шпицбергене, Земле Франца Иосифа и Новой Земле не один год.

С 1 декабря 1948 года и по 1992 год М.П. работала в Воронежском педагогическом институте, пройдя путь от ассистента до профессора, с честью неся и передавая эстафету традиций альмаматер. В 1970 году ею успешно защищена докторская диссертация на тему «Основные проблемы физико-географического районирования Африки (история становления и опыт решения)» в городе Минск в Белорусском государственном университет им. В. И. Ленина. Официальными оппонента- ми по диссертации выступали профессор М. А. Гвоздецкий, профессор Ю. Д. Дмитриевский, профессор А.Х. Шкляр, а ведущей организацией была кафедра физической географии зарубежных стран МГУ им. М.И. Ломоносова, руководимая профессором А. М. Рябчиковым. Мария Павловна успешно сочетала научную, учебно-методическую работы с заведыванием поочередно кафедрами экономической (1976-1983 гг.) и физической (19871988 гг.) географии.

По воспоминаниям ее учеников и сотрудников Мария Павловна Забродская проявила себя как методист, учитель учителей, глубокий до тонкостей знаток и самозабвенный любитель ландшафтов Африки. Она во истину была одержима в научной работе. Мария Павловна часто говорила о том, что иметь в жизни цель - счастье, без нее жизнь бессмысленна и горька. Она для счастья выбрала высокую цель: накопление умственного и душевного богатства. За многие годы ею по крупицам были накоплены капитальные, глубокие знания, высокая общая и профессиональная культура, разносторонняя содержательность и высокая нравственность.

Область научных интересов М.П. Забродской являлась физическая география Африки, ее труды по этой проблеме известны географам нашей страны [1]. Однако проблематика научных работ разнообразна и условно ее можно разделить на следующие группы: 1) проблемы физико-географического районирования Африки, структура природных зон и их агроклиматические характеристики; 2) история исследования великих русских путешественников Африки; 3) методология комплексного географического анализа территории зарубежных стран мира на примере государств Африки; 4) факторы пространственной дифференциации материков; 5) географические аналоги природных зон Африки, территории Евразии, Австралии и Южной Америки.

За время профессиональной деятельности, М.П. Забродской опубликовано более 90 крупных научно-исследовательских и методических работ. Среди страноведов Мария Павловна Забродская считалась известным теоретическим исследователем Африки. Много работала с архивными материалами, дневниками русских путешественников, обобщила и проанализировала материал, выявила закономерности и установила взаимосвязи между компонентами природы на Африканском континенте. Значительное внимание в ее трудах было уделено геоморфологическим процессам и кли- 
матическому районированию Африки. Она открыла имена многих русских путешественников по Африке и определила их вклад в ее изучение.

Особое место занимает историко-географический анализ первоисточников. Одна из работ Марии Павловны посвящена изучению географических исследований А. В. Елисеева, который проводил антропологические и этнологические наблюдения за туарегами в Африке. Мария Павловна доказала, что А. В. Елисеева можно считать основоположником такого направления, как художественная география. Он является одним из пионеров развития экологической географии, так как обращал внимание на взаимосвязи человека и природы. Также в его работах заложены основы комплексной географии, а его труды были отмечены золотой и серебряной медалью Русского географического общества [2].

Работы М.П. Забродской актуальны в настоящее время, так как в последние годы не проводились крупные географические исследования в области физической географии Африки.

Особое научно-методическое направление профессора М.П. Забродской составляют работы по теоретическим проблемам учебных курсов географии, в частности по совершенствованию методики изучения физической географии материков в педагогических вузах. Среди них можно отметить, методическое пособие по физико-географическому обзору Южной Америки, учебное пособие и практикум по физической географии Африки, практические и межсессионные задания по физической географии материков. Разработанные М. П. Забродской методические приемы по изучению курсов страноведения актуальны и в настоя-

\section{КОНФЛИКТ ИНТЕРЕСОВ}

Авторы декларируют отсутствие явных и потенциальных конфликтов интересов, связанных с публикацией настоящей статьи.

Луговской Александр Михайлович

доктор географических наук, профессор, Московский государственный университет геодезии и картографии (МИИГАиК), г. Москва, Российская Федерация, ORCID: https://orcid.org/0000-0002-3985-4535

Межова Лидия Александровна

кандидат географических наук, доцент, Воронежский государственный педагогический университет, г. Воронеж, Российская Федерация, ORCID: https://orcid.org/ 0000-0002-6652-5120, E-mail: lidiya09@ rambler.ru щее время. Особое внимание заслуживает курс лекций по пространственной дифференциации материков, выполненный также на примере Африки.

Много сил отдавала Мария Павловна организации и руководству студенческой наукой. Под ее руководством ежегодно выполнялись очень интересные и глубокие дипломные работы.

Мария Павловна Забродская для всех поколений студентов-географов была замечательным, требовательным Учителем, образцом служения своему долгу, воспитателем молодежи, развивала жажду познания, прививала географическую культуру. Она снискала глубокое уважение географов, ее педагогический труд был отмечен государственными наградами - медалью «За трудовую доблесть» и знаком «Отличник просвещения».

С чувством гражданской ответственности выполняла свою жизненную миссию наилучшим образом. Сотни людей, получивших географическое образование, остались благодарны ей на всю жизнь.

\section{СПИСОК ЛИТЕРАТУРЫ}

1. Забродская М.П. Русские путешественники по Африке. Москва, Географгиз, 1955. 88 с.

2. Забродская М. П. Путешествие А. В. Елисеева по Caхape (1881-1893 гг.) // География. Этнография. История, 1987, вып. XXV, с. 34-40.

\section{REFERENCES}

1. Zabrodskaya M.P. Russkie puteshestvenniki po Afrike [Russian travelers in Africa]. Moskow, Geografgiz, 1955. $88 \mathrm{p}$.

2. Zabrodskaya M.P. Puteshestvie A. V. Eliseeva po Sahare (1881-1893 gg.) [Eliseev's trip to the Sahara (18811893)]. Geografiya. Etnografiya. Istoriya, 1987, v. XXV, pp. 34-40.

\section{CONFLICT OF INTEREST}

The authors declare no information of obvious and potential conflicts of interest related to the publication of this article.

\section{Alexander M. Lugovskoy}

Dr. Sci. (Geogr.), Full Prof., Moscow State University of Geodesy and Cartography (MIGAIK), Moscow, Russian Federation, ORCID: https://orcid.org/0000-0002-3985-4535

Lydia A. Mezhova

Cand. Sci. (Geogr.), Assoc. Prof., Voronezh State Pedagogical University, Voronezh, Russian Federation, ORCID: https://orcid.org/0000-0002-6652-5120, e-mail: lidiya09@rambler.ru 